\title{
Promoters for Pd-catalyzed methoxycarbonylation of vinyl acetate
}

\author{
Ivan A. Shuklov, ${ }^{\text {a* Natalia V. Dubrovina, }{ }^{a} \text { Joachim Schulze, }{ }^{b} \text { Wolfgang Tietz, }}$ \\ Klaus Kühlein, ${ }^{c}$ and Armin Börner ${ }^{\text {a,d* }}$ \\ ${ }^{a}$ Leibniz-Institut für Katalyse an der Universität Rostock e.V., A.-Einstein-Str. 29a, 18059 \\ Rostock, Germany \\ ${ }^{b}$ Uhde GmbH, Hans-Weigel-Str. 2a, 04319 Leipzig, Germany \\ ${ }^{c}$ Fasanenstr. 41, 65779 Kelkheim, Germany \\ ${ }^{d}$ Institut für Chemie der Universität Rostock, A.-Einstein-Str. 3a, 18059 Rostock, Germany. \\ E-mail:1van.shuklov@catalysis.de,armin.boerner@catalysis.de
}

\section{Dedicated to Professor Rainer Beckert on the occasion of his 60th birthday}

\begin{abstract}
A study on the influence of acidic and non-acidic promoters for $\mathrm{Pd}\left(\mathrm{PPh}_{3}\right)$-catalyzed methoxycarbonylation of vinyl acetate was conducted in order to find an efficient protocol for the synthesis of methyl $O$-acetyl lactate. Besides known promoters also some new catalytic systems were tested. Aluminium triflate is the most active additive.
\end{abstract}

Keywords: Alkoxycarbonylation, palladium, lactic acid, additive

\section{Introduction}

Lactic acid and its derivatives are important chemicals and synthetic building blocks for food and polymer industry. Of particular interest is poly(L-lactide) (PLLA) derived from natural L-lactic acid. PLLA is a biodegradable polymer. ${ }^{1}$ This property gives it a broad potential for applications with special focus on ecological aspects. It is assumed that PLLA can be employed in the same scale like polyethylene terephthalate (PET). ${ }^{2}$ Moreover, ethyl lactate is considered as a green solvent with potential in organic synthesis. ${ }^{3}$

Manufacturing of large amount of lactates is limited by the currently performed biochemical synthesis. Massive amounts of calcium sulfate as a waste product are generated during the isolation of lactic acid from fermentation broth. "Grass-covered mounds of calcium sulphate" usually surround lactic acid plants. ${ }^{4}$ This feature makes the search for alternative synthetic pathways to lactates attractive. 
Methoxycarbonylation of vinyl acetate seems to be a promising chemical venue to lactoyl esters. The starting material is a cheap, commercially available compound synthesized from ethylene and acetic acid. Alkoxycarbonylation is usually catalyzed by homogeneous palladium complexes that makes this transformation attractive from economical as well as from ecological point of view. ${ }^{5}$

Despite of some success achieved in recent years, the alkoxycarbonylation of vinyl acetate is still far from industrial application. Large amounts of expensive and air-sensitive phosphine ligands are necessary to catalyse this transformation effectively. ${ }^{6}$ Nevertheless some promising results with low loads of simple phosphines in the presence of promoters were published. ${ }^{7,8}$ However these systems demand further improvement concerning activity and selectivity.

In principle methoxycarbonylaton of vinyl acetate leads to the formation of the branched $(b)$ and the linear $(l)$ product, only the former is desired (Scheme 1). Moreover, since the catalytic reaction is usually run in the presence of strong acids ${ }^{9}$ the starting product may easily undergo transesterification under the formation of methyl acetate and acetaldehyde dimethylacetal. Methanolysis of the acetoxy group in the product gives methyl lactate. These facts have to be carefully considered by selection of the reaction conditions.

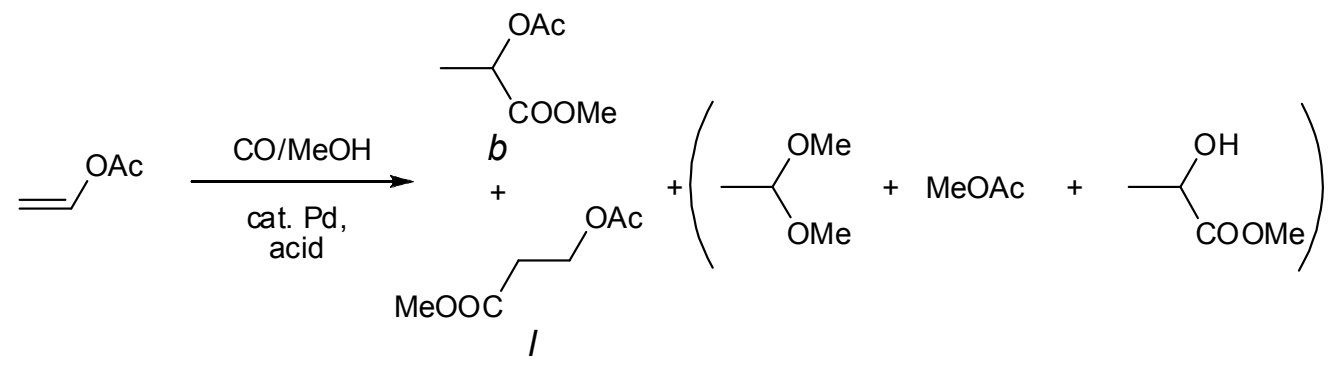

Scheme 1. Methoxycarbonylation of vinyl acetate.

Herein we report on our results on the Pd-catalyzed methoxycarbonylation of vinyl acetate in the presence of different additives. Triphenylphosphine was used as ligand for palladium because it is especial attractive in terms of stability and cost. Three type of promoters were tested: Brønsted-acids, Lewis acids and some none acidic promoters, such as nitrogen heterocycles and 1,3-dicarbonyl compounds.

\section{Results and Discussion}

\section{The effect of Brønsted-acids as promoters}

A generally accepted mechanism of methoxycarbonylation consists of two catalytic cycles: hydride and methoxycarbonyl mechanism. ${ }^{10,11}$ Heaton and co-workers gave evidence that the former is favored. ${ }^{10}$ In this connectivity protic promoters serve as hydride source for the formation of a catalytically active Pd-hydride and initiate thus the reaction. It is generally 
assumed, that best promoters are strong acids with weak coordinating ability. ${ }^{10,11}$ Only a few carboxylic acids were investigated for this purpose. ${ }^{12}$ For example, propionic acid was used as promoter in the alkoxycarbonylation of ethene with $n$-butanol. ${ }^{12 \mathrm{a}}$

First we studied the influence of the $\mathrm{p} K_{\mathrm{a}}$ of protic acids on the rate of the methoxycarbonylation and the methoxylation as most important side reaction. As Brønsted-acids weak carboxylic acid, such as salicylic, benzoic, citric, oxalic and $O$-acetyl lactic acid but also hexafluoroisopropanol (HFIP) and phenol were tested (Table 1). The reaction to the carboxylation products proceeds extremely slow without any promoter or in the presence of very weak acids such as phenol (Runs 1,2). Apparently, HFIP $\left(\mathrm{p} K_{\mathrm{a}}=9.3\right)$ is sufficiently acidic in order to accelerate the reaction (Run 3). ${ }^{13}$ But in general the reaction rate was low. The application of carboxylic acids gave much better results. In particular the high regioselectivities are noteworthy (Runs 4-7, 10). The reaction was always accompanied by methanolysis of the product to give methyl lactate. The yields of the desired product dropped by employment of stronger acids such as methanesulfonic acid and $p$-toluenesulfonic acid due to alcoholysis (Runs $6,7)$. In all cases methyl acetate and acetaldehyde dimethylacetal were detected as by-products.

Table 1. Methoxycarbonylation with Brønsted acids as promoters ${ }^{\mathrm{a}}$

\begin{tabular}{cccccc}
\hline Run & Additive & $\mathrm{pK}_{\mathrm{a}}\left(\mathrm{H}_{2} \mathrm{O}\right)$ & $\begin{array}{c}\text { Conversion }^{\mathrm{b}} \\
{[\%]}\end{array}$ & $\begin{array}{c}\text { Yield }^{\mathrm{b}, \mathrm{c}} \\
{[\%]}\end{array}$ & $b: l^{\mathrm{b}}$ \\
\hline 1 & - & - & 70 & 2 & - \\
2 & $\mathrm{PhOH}$ & 9.95 & 20 & 1.5 & $1: 6$ \\
3 & $\left(\mathrm{CF}_{3}\right)_{2} \mathrm{CHOH}(\mathrm{HFIP})$ & 9.3 & 72 & 19 & $15: 1$ \\
4 & $(\mathrm{COOH})_{2}$ & 1.25 & 82 & $40(14)$ & $20: 1$ \\
5 & Salicylic acid & 2.97 & 80 & $37(13)$ & $19: 1$ \\
6 & Benzoic acid & 4.2 & 85 & $39(15)$ & $19: 1$ \\
7 & Citric acid & 3.13 & 90 & $42(18)$ & $19: 1$ \\
8 & MeSO & 85 & $28(7)$ & $25: 1$ \\
9 & $p-$ TsOH $_{1}$ & -2.6 & 99 & $12(9)$ & - \\
10 & $O-$-Ac-Lactic acid & -0.51 & 75 & $31(10)$ & $16: 1$ \\
\hline
\end{tabular}

${ }^{\mathrm{a}}$ Reaction conditions: 50 bar $\mathrm{CO}, 100{ }^{\circ} \mathrm{C}, 10 \mathrm{~mL}$ toluene, $0.025 \mathrm{mmol} \mathrm{Pd}(\mathrm{PhCN})_{2} \mathrm{Cl}_{2}, 0.05$ mmol $\mathrm{PPh}_{3}, 0.05 \mathrm{mmol}$ additive, $1.2 \mathrm{~mL}(30 \mathrm{mmol}) \mathrm{MeOH}, 1.1 \mathrm{~mL}(12 \mathrm{mmol})$ vinyl acetate, 15 h. ${ }^{b}$ Determined by GC. ${ }^{c}$ Yield of methoxycarbonylation products. Yield of methyl lactate in brackets.

Obviously, the application of weak carboxylic acid as promoters seems to be more advantageous, because alcoholysis of the starting material is decelerated.

Solid acids such as the sulfonated polystyrene polymere Amberlite 120 and strongly acidic Zeolite HY CBV-400 were tested too (Table 2). 
Table 2. Methoxycarbonylation with solid acids as promoters ${ }^{\mathrm{a}}$

\begin{tabular}{ccccc}
\hline Run & Additive & $\begin{array}{c}\text { Conversion }^{\text {b }} \\
{[\%]}\end{array}$ & $\begin{array}{c}\text { Yield }^{\text {b,c }} \\
{[\%]}\end{array}$ & $b: l^{\text {b }}$ \\
\hline $1^{\text {d }}$ & Amberlite 120 & 85 & $37(7)$ & $20: 1$ \\
2 & Amberlite 120 & 85 & $36(10)$ & $20: 1$ \\
3 & Zeolite & 80 & $33(11)$ & $20: 1$ \\
4 & Amberlite 120 + Py & 50 & 43 & $32: 1$ \\
5 & Zeolite + Py & 43 & 30 & $25: 1$ \\
\hline
\end{tabular}

${ }^{\mathrm{a}}$ Reaction conditions: 50 bar $\mathrm{CO}, 100{ }^{\circ} \mathrm{C}, 10 \mathrm{~mL}$ toluene, $0.025 \mathrm{mmol} \mathrm{Pd}\left(\mathrm{PhCN}_{2} \mathrm{Cl}_{2}, 0.05 \mathrm{mmol}\right.$ $\mathrm{PPh}_{3}, 50 \mathrm{mg}$ additive, $1.2 \mathrm{~mL}(30 \mathrm{mmol}) \mathrm{MeOH}, 1.1 \mathrm{~mL}(12 \mathrm{mmol})$ vinyl acetate, $15 \mathrm{~h}$; ${ }^{b}$ Determined by GC. ${ }^{c}$ Yield of methoxycarbonylation products. Yield of methyl lactate in brackets. ${ }^{\mathrm{d}} 10 \mathrm{mg}$ additive was added.

Both promoters beneficially affect the reaction. The regioselectivities 20:1 are typical for protic additives (Runs 1-3). Addition of pyridine suppressed the formation of methyl lactate and increased the formation of the desired branched product (Runs 4,5).

\section{None acidic promoters}

Several none acidic additives have been suggested as promoters for methoxycarbonylation. ${ }^{7,8}$ In particular pyridine and related compounds were tested for the transformation of various olefins. ${ }^{14}$ The role of these weak bases is not clear up to now and can probably vary for each catalytic system. Hayashi et al. claimed a stabilizing effect of $N$-bases which prevents the formation of metallic palladium. ${ }^{14 b} \mathrm{D}$ 'Amore suggested a role as a scavenger for chloride anions released by strong acids from catalyst presursors. ${ }^{14 \mathrm{c}}$

We tested several nitrogen heterocycles such as pyridine, 2,4-collidine, 2,5,6-lutidine, quinoline, 1,10-phenanthroline, imidazole, 1,4-diazabicylco[2.2.2] octane (DABCO) and 2,2'bipyridine (Table 3).

Best results in terms of yield and conversion were obtained with pyridine and quinoline (Runs 1,4). Nitrogen heterocycles decrease the rate of the alcoholysis of the product, probably by acting as a basic buffer. Sterically hindered pyridines are less effective (Runs 6-8). The yield of the methoxycarbonylation product drops with increasing number of $\alpha$-substituents in the heterocyle. This observation may serve as an indirect evidence of pyridine complexation in the catalytic intermediates, because bulky substituents will prevent the complexation of the promoter on the metal. Remarkably, strong chelating promotors such as phenanthroline inhibit the reaction (Run 12).

Acetylacetone was found as a promoter by Chaudhari et al. but no rationalization for the effect was given. ${ }^{8}$ Our experiments indicate that this weak acid may facilitate the removal of chloride from the palladium precursor by formation of hydrochloric acid. This hypothesis is supported by the observation of alcoholysis products at elevated temperature (Table 4, Runs 1,2). 
The observed regioselectivity in the product is similar to that found with acidic promoters. Other 1,3-dicarbonyl compounds such as methyl acetoacetate and ethyl benzoylacetate gave similar results (Runs 3,4).

Table 3. Methoxycarbonylation with nitrogen heterocycles as promoters ${ }^{\mathrm{a}}$

\begin{tabular}{ccccccc}
\hline Run & Additive & $\begin{array}{c}p \text {-TsOH } \\
\text { Mmol }\end{array}$ & $\begin{array}{c}T \\
{\left[{ }^{\circ} \mathrm{C}\right]}\end{array}$ & $\begin{array}{c}\text { Conversion }^{\mathrm{b}} \\
{[\%]}\end{array}$ & $\begin{array}{c}\text { Yield }^{\mathrm{b}, \mathrm{c}} \\
{[\%]}\end{array}$ & $b^{b} l^{\mathrm{b}}$ \\
\hline 1 & Pyridine & 0.01 & 100 & 65 & $42(7)$ & $40: 1$ \\
2 & Pyridine & 0.01 & 80 & 22 & 11 & $20: 1$ \\
3 & Pyridine & 0.1 & 100 & 75 & $20(4)$ & $11: 1$ \\
4 & Quinoline & 0.1 & 100 & 70 & $44(5)$ & $30: 1$ \\
5 & Quinoline & 0.01 & 100 & 60 & $34(3)$ & $25: 1$ \\
6 & 2,4,6-Collidine & 0.01 & 100 & 20 & 5 & - \\
7 & 2,4-Lutidine & 0.1 & 100 & 20 & 13 & $10: 1$ \\
8 & 2,4-Lutidine & 0.01 & 100 & 10 & 7 & - \\
9 & Imidazole & 0.01 & 100 & 30 & traces & - \\
10 & DABCO & 0.01 & 100 & 90 & 6 & - \\
11 & Bipyridine & 0.01 & 100 & 70 & $39(9)$ & $99: 1$ \\
12 & 1,10 -Phenanthroline & 0.01 & 100 & 20 & 1 & - \\
\hline
\end{tabular}

${ }^{\mathrm{a}}$ Reaction conditions: 50 bar $\mathrm{CO}, 10 \mathrm{~mL}$ toluene, $0.025 \mathrm{mmol} \mathrm{Pd}(\mathrm{PhCN})_{2} \mathrm{Cl}_{2}, 0.05 \mathrm{mmol} \mathrm{PPh}_{3}$, $0.5 \mathrm{mmol}$ additive, $p$-TsOH, $1.2 \mathrm{~mL}(30 \mathrm{mmol}) \mathrm{MeOH}, 1.1 \mathrm{~mL}(12 \mathrm{mmol})$ vinyl acetate, $15 \mathrm{~h}$. ${ }^{b}$ Determined by GC. ${ }^{c}$ Yield of methoxycarbonylation products. Yield of methyl lactate in brackets.

Our rationalization on the effect of acetylacetone is additionally supported by the complete failure of $\mathrm{Pd}(\mathrm{acac})_{2}$ which is not able to provide the required proton (Run 5,6). Similarly only marginal amounts of the product could be detected in the presence of additional lithium chloride as a source of chloride ions (Run 7).

The successful application of pyridine and carboxylic acids as promoters inspired us to investigate the methoxycarbonylation in the presence of phosphines containing additional functional groups such as carboxyl and pyridinyl substituents. These compounds combine promoter and ligating function (Table 5). Activity and regioselectivity strongly depend on the position of the second functional group (Runs 1-3). The catalyst based on the para-carboxylic acid substituted phenyldiphenylphosphine was more active that its ortho-analogue. 2Pyridinyldiphenylphosphine failed as promoter, even in the presence of an acidic additive (Runs 4-7). 
Table 4. Methoxycarbonylation in the presence of non-acidic additives ${ }^{\mathrm{a}}$

\begin{tabular}{ccccccc}
\hline Run & Pd-precursor & Additive & $\begin{array}{c}T \\
{\left[{ }^{\circ} \mathrm{C}\right]}\end{array}$ & $\begin{array}{c}\text { Conversion }^{\mathrm{b}} \\
{[\%]}\end{array}$ & $\begin{array}{c}\text { Yield }^{\mathrm{b}, \mathrm{c}} \\
{[\%]}\end{array}$ & $b^{\text {b: }} l^{\mathrm{b}}$ \\
\hline 1 & $\mathrm{Pd}(\mathrm{PhCN})_{2} \mathrm{Cl}_{2}$ & Acetylacetone & 100 & 89 & $32(12)$ & $20: 1$ \\
2 & $\mathrm{Pd}(\mathrm{PhCN})_{2} \mathrm{Cl}_{2}$ & Acetylacetone & 80 & 45 & 23 & $17: 1$ \\
3 & $\mathrm{Pd}(\mathrm{PhCN})_{2} \mathrm{Cl}_{2}$ & Methyl acetoacetate & 100 & 60 & $24(5)$ & $20: 1$ \\
4 & $\mathrm{Pd}(\mathrm{PhCN})_{2} \mathrm{Cl}_{2}$ & Ethyl benzoylacetate & 100 & 80 & $35(11)$ & $30: 1$ \\
5 & $\mathrm{Pd}(\mathrm{acac})_{2}$ & - & 80 & 12 & - & - \\
6 & $\mathrm{Pd}(\mathrm{acac})_{2}$ & - & 100 & 20 & - & - \\
7 & $\mathrm{Pd}(\mathrm{acac})_{2}$ & $\mathrm{LiCl}$ & 100 & 25 & 1 & - \\
\hline
\end{tabular}

${ }^{a}$ Reaction conditions: 50 bar $\mathrm{CO}, 10 \mathrm{~mL}$ toluene, $0.025 \mathrm{mmol}$ Pd-precursor, $0.05 \mathrm{mmol} \mathrm{PPh}_{3}, 0.5$ mmol additive, $1.2 \mathrm{~mL}$ (30 mmol) MeOH, $1.1 \mathrm{~mL}(12 \mathrm{mmol})$ vinyl acetate, $15 \mathrm{~h} .{ }^{b}$ Determined by GC. ${ }^{\mathrm{c}}$ Yield of methoxycarbonylation products. Yield of methyl lactate in brackets.

Table 5. Methoxycarbonylation of vinyl acetate with ligand based promoters ${ }^{\mathrm{a}}$

\begin{tabular}{cccccc}
\hline Run & Ligand & Additive & $\begin{array}{c}\text { Conversion }^{\mathrm{b}} \\
{[\%]}\end{array}$ & $\begin{array}{c}\text { Yield }^{\mathrm{b}, \mathrm{c}} \\
{[\%]}\end{array}$ & $b: l^{\mathrm{b}}$ \\
\hline 1 & $o-\mathrm{PPh}_{2}-\mathrm{Ph}-\mathrm{COOH}$ & - & 33 & 6 & $9: 1$ \\
2 & $o-\mathrm{PPh}_{2}-\mathrm{Ph}-\mathrm{COOH}$ & $\mathrm{Py}^{\mathrm{d}}$ & 38 & 9 & $9: 1$ \\
3 & $p-\mathrm{PPh}_{2}-\mathrm{Ph}-\mathrm{COOH}$ & $\mathrm{Py}^{\mathrm{d}}$ & 60 & 42 & $27: 1$ \\
4 & $2-\mathrm{PPh}_{2} \mathrm{Py}$ & - & 13 & 4 & $4: 1$ \\
5 & $2-\mathrm{PPh}_{2} \mathrm{Py}$ & $\mathrm{AcAc}^{\mathrm{d}}$ & 15 & 3 & $3: 1$ \\
6 & $2-\mathrm{PPh}_{2} \mathrm{Py}^{\mathrm{P}}$ & $\mathrm{MeSO}_{3} \mathrm{H}^{\mathrm{e}}$ & 50 & 3 & $3: 1$ \\
7 & $2-\mathrm{PPh}_{2} \mathrm{Py}^{\mathrm{f}}$ & - & 10 & 3 & $2: 1$ \\
\hline
\end{tabular}

${ }^{\mathrm{a}}$ Reaction conditions: 50 bar $\mathrm{CO}, 100{ }^{\circ} \mathrm{C}, 10 \mathrm{~mL}$ toluene, $0.025 \mathrm{mmol} \mathrm{Pd}\left(\mathrm{PhCN}_{2} \mathrm{Cl}_{2}, 0.05 \mathrm{mmol}\right.$ ligand, $1.2 \mathrm{~mL}(30 \mathrm{mmol}) \mathrm{MeOH}, 1.1 \mathrm{~mL}(12 \mathrm{mmol})$ vinyl acetate, $15 \mathrm{~h}$. ${ }^{\mathrm{b}}$ Determined by GC. ${ }^{c}$ Yield of methoxycarbonylation products. Yield of methyl lactate in brackets. ${ }^{\mathrm{d}} 0.5 \mathrm{mmol}$ additive. ${ }^{\mathrm{e}} 0.05 \mathrm{mmol}$ additive. ${ }^{\mathrm{f}} 0.1 \mathrm{mmol}$ phosphine.

The role of the catalyst precursor was investigated with two promoters namely acetylacetone and pyridine $/ p-\mathrm{TsOH}$ (Table 6). Methoxycarbonylation with $\mathrm{Pd}(\mathrm{OAc})_{2}$ gave poor conversion and did not lead to the desired product (Runs 1,2). Much better results were obtained with $\mathrm{PdCl}_{2}$, $\mathrm{Pd}\left(\mathrm{PPh}_{3}\right)_{2} \mathrm{Cl}_{2}$ and a corresponding benzonitrile complex (Runs 3-8). 
Table 6. Influence of Pd-precursor ${ }^{\mathrm{a}}$

\begin{tabular}{cccccc}
\hline Run & Additive & Pd-Precursor & $\begin{array}{c}\text { Conversion }^{\mathrm{b}} \\
{[\%]}\end{array}$ & $\begin{array}{c}\text { Yield }^{\mathrm{b}, \mathrm{c}} \\
{[\%]}\end{array}$ & $b: l^{\mathrm{b}}$ \\
\hline $1^{\mathrm{d}}$ & Acetylacetone & $\mathrm{Pd}(\mathrm{OAc})_{2}$ & 15 & - & - \\
$2^{\mathrm{e}}$ & $\mathrm{Py}+p$-TsOH & $\mathrm{Pd}(\mathrm{OAc})_{2}$ & 5 & 2 & - \\
$3^{\mathrm{d}}$ & Acetylacetone & $\mathrm{PdCl}_{2}$ & 86 & $39(12)$ & $20: 1$ \\
$4^{\mathrm{e}}$ & Py $+p$-TsOH & $\mathrm{PdCl}_{2}$ & 65 & 58 & $33: 1$ \\
$5^{\mathrm{d}, \mathrm{f}}$ & Acetylacetone & ${\mathrm{Pd}\left(\mathrm{PPh}_{3}\right)_{2} \mathrm{Cl}_{2}}^{\mathrm{e}}$ & 25 & 12 & - \\
$6^{\mathrm{e}, \mathrm{f}}$ & Py $+p$-TsOH & ${\mathrm{Pd}\left(\mathrm{PPh}_{3}\right)_{2} \mathrm{Cl}_{2}}^{\mathrm{C}}$ & 70 & 62 & $35: 1$ \\
$7^{\mathrm{e}}$ & Acetylacetone & $\mathrm{Pd}\left(\mathrm{PhCN}_{2} \mathrm{Cl}_{2}\right.$ & 89 & $32(12)$ & $20: 1$ \\
$8^{\mathrm{d}}$ & $\mathrm{Py}+p$-TsOH & $\mathrm{Pd}(\mathrm{PhCN})_{2} \mathrm{Cl}_{2}$ & 61 & 43 & $40: 1$ \\
\hline
\end{tabular}

${ }^{\mathrm{a}}$ Reaction conditions: 50 bar $\mathrm{CO}, 100{ }^{\circ} \mathrm{C}, 10 \mathrm{~mL}$ toluene, $0.025 \mathrm{mmol}$ Pd-precursor, $0.05 \mathrm{mmol}$ $\mathrm{PPh}_{3}, 1.2 \mathrm{~mL}(30 \mathrm{mmol}) \mathrm{MeOH}, 1.1 \mathrm{~mL}(12 \mathrm{mmol})$ vinyl acetate, $15 \mathrm{~h} .{ }^{\mathrm{b}}$ Determined by GC. ${ }^{c}$ Yield of methoxycarbonylation products. Yield of methyl lactate in brackets. ${ }^{\mathrm{d}} 0.5 \mathrm{mmol}$ acetylacetone. ${ }^{\mathrm{e}} 0.5 \mathrm{mmol}$ pyridine, $0.01 \mathrm{mmol} p-\mathrm{TsOH} .{ }^{\mathrm{f}} \mathrm{No}$ additional $\mathrm{PPh}_{3}$ was added.

\section{Lewis acids as promoters}

Finally we have tested Lewis acids as promoters. The utility of aluminium triflate as an additive in Pd-catalyzed methoxycarbonylation of styrene and pentene-1 was shown recently. ${ }^{15}$ In general in the methoxycarbonylation of vinyl acetate the regioselectivity in the presence of triflates significantly differs from the selectivities obtained with Brønsted acids (compare results of Table 1 and Table 7). Thus the $b: l$ ratio remains constant at $1: 1$ independent on the amount of $\mathrm{Al}(\mathrm{OTf})_{3}$ (Runs 1-4). At a temperature of $100{ }^{\circ} \mathrm{C} 72 \%$ yield of the methoxycarbonylation products was achieved (Run 4). The addition of $\mathrm{AlCl}_{3}$ gave much higher selectivity for the formation of the branched product, but lowered the yield (Run 5). Yttrium and ytterbium triflates gave inferior results. Moreover, the use of these monohydrates caused the precipitation of black palladium and polymerisation of the organic material, respectively.

Table 7. Methoxycarbonylation in the presence of Lewis-acids as promoters ${ }^{\mathrm{a}}$

\begin{tabular}{cccccc}
\hline Run & Additive & $\begin{array}{c}\mathrm{T} \\
{\left[{ }^{\circ} \mathrm{C}\right]}\end{array}$ & $\begin{array}{c}\text { Conversion }^{\mathrm{b}} \\
{[\%]}\end{array}$ & $\begin{array}{c}\text { Yield }^{\mathrm{b}, \mathrm{c}} \\
{[\%]}\end{array}$ & $b: l^{\mathrm{b}}$ \\
\hline $1^{\mathrm{d}}$ & $\mathrm{Al}(\mathrm{OTf})_{3}$ & 80 & 50 & 18 & $1: 1$ \\
$2^{\mathrm{d}}$ & $\mathrm{Al}(\mathrm{OTf})_{3}$ & 100 & 85 & 58 & $1: 1$ \\
3 & $\mathrm{Al}(\mathrm{OTf})_{3}$ & 80 & 80 & 36 & $1: 1$ \\
4 & $\mathrm{Al}(\mathrm{OTf})_{3}$ & 100 & 85 & 72 & $1: 1$ \\
5 & $\mathrm{AlCl}_{3}$ & 100 & 85 & $30(7)$ & $20: 1$ \\
6 & $\mathrm{Y}(\mathrm{OTf})_{3} * \mathrm{H}_{2} \mathrm{O}$ & 100 & 80 & 14 & $1: 1$ \\
7 & $\mathrm{Yb}(\mathrm{OTf})_{3} * \mathrm{H}_{2} \mathrm{O}$ & 100 & 80 & 37 & $1.2: 1$ \\
8 & $\mathrm{SnCl}_{2} * \mathrm{H}_{2} \mathrm{O}$ & 100 & 75 & 12 & $4: 1$ \\
\hline
\end{tabular}


${ }^{\mathrm{a}}$ Reaction conditions: 50 bar $\mathrm{CO}, 10 \mathrm{~mL}$ toluene, $0.045 \mathrm{mmol} \mathrm{Pd}(\mathrm{OAc})_{2}, 0.18 \mathrm{mmol} \mathrm{PPh}_{3}, 0.09$ mmol additive, $1.2 \mathrm{~mL}(30 \mathrm{mmol}) \mathrm{MeOH}, 1.1 \mathrm{~mL}(12 \mathrm{mmol})$ vinyl acetate, $15 \mathrm{~h}$. ${ }^{\mathrm{b}}$ Determined by GC. ${ }^{c}$ Yield of methoxycarbonylation products. Yield of methyl lactate in brackets. ${ }^{\mathrm{d}} 0.045 \mathrm{mmol}$ additive.

\section{Summary and Conclusions}

Several types of promoters such as Brønsted and Lewis acids, nitrogen heterocycles and 1,3dicarbonyl compounds suggested in the literature for the Pd-catalyzed alkoxycarbonylation of alkenes were tested for the methoxycarbonylation of vinyl acetate. As ligand for palladium $\mathrm{PPh}_{3}$ was used. The effect of 1,3-dicarbonyl compounds and nitrogen heterocyclic compounds was investigated and clarified. Some new acidic promoters were identified such as salicylic and benzoic acids as well as Zeolite HY CBV-400. With these promotors extremely high $b / l$-ratios were noted. Lower $b / l$-ratio but superior results in terms of conversion and yield were obtained with aluminium triflate. After liberation of the free lactic acid by saponification the racemic compound can be subjected to kinetic resolution in order to obtain the enantiomerically pure acid required for the synthesis of PLLA.

\section{Experimental Section}

General. All manipulations of air-sensitive materials were carried out in oven-dried glassware by using standard Schlenk techniques under Ar. Solid and liquid chemicals were purchased from Aldrich, Acros and Strem as received. All gases were purchased from Air Liquide. Toluene was distilled over sodium diphenylketyl. Vinyl acetate was distilled over $\mathrm{CaCl}_{2}$ and stored at $0{ }^{\circ} \mathrm{C}$ in a flask wrapped in tinfoil to exclude light. For the determination of conversion a GC column (50 m HP5) was used. ${ }^{1} \mathrm{H}$ and ${ }^{13} \mathrm{C}$ NMR spectroscopic data were measured on solutions in $\mathrm{CDCl}_{3}$ and $\mathrm{MeOH}-\mathrm{d}_{4}$ at $300 \mathrm{MHz}$. Proton chemical shifts were referenced to tetramethylsilane as standard. Carbon chemical shifts were referenced to the carbon signal of the solvent at $\delta 77.0$ ppm.

\section{General procedure for methoxycarbonylation of vinyl acetate}

The Schlenk tube was charged with $\mathrm{Pd}(\mathrm{OAc})_{2},(8 \mathrm{mg}, 0.045 \mathrm{mmol}), \mathrm{PPh}_{3}(47 \mathrm{mg}, 0.05 \mathrm{mmol})$, $\mathrm{MeOH}(1.2 \mathrm{ml}, 30 \mathrm{mmol}), \mathrm{Al}(\mathrm{OTf})_{3}(42.6 \mathrm{mg}, 0.9 \mathrm{mmol})$ and abs. degassed toluene $(10 \mathrm{~mL})$ at r.t.. The mixture was stirred for 60 minutes. Then vinyl acetate $(1.1 \mathrm{~mL}, 12 \mathrm{mmol})$ was added and the mixture immediately transferred in a $25 \mathrm{~mL}$ autoclave. The autoclave was flushed three times with $\mathrm{CO}$ and subsequently heated up to $100^{\circ} \mathrm{C}$. Then the vessel was pressurized with $\mathrm{CO}$ to 50 bars. The reaction mixture was stirred at $100{ }^{\circ} \mathrm{C}$ for $15 \mathrm{~h}$. Finally the autoclave was cooled 
down to room temperature and the $\mathrm{CO}$ vented off. The composition of the reaction mixture was analyzed by gas chromatography.

\section{Acknowledgements}

We acknowledge the financial support by Uhde $\mathrm{GmbH}$ Leipzig. The authors thank Dr. C. Fischer, S. Buchholz, and S. Schareina for excellent analytical support.

\section{References and Notes}

1. Garlotta, D. J. Polym. Environment 2001, 9, 63. (b) Gattin, R.; Copinet, A.; Bertrand, C.; Couturier, Y. J. Polym. Environment 2001, 9, 11. (c) Numata, K.; Srivastava, R. K.; FinneWistrand, A.; Albertsson, A.-C.; Doi, Y.; Abe, H. Biomacromolecules 2007, 8, 3115. (d) Endres, H.-J.; Siebert-Raths, A. Technische Biopolymere. Hanser-Verlag, München 2009, p 293. (e) Poly(Lactic Acid), Synthesis, Structures, Properties, Processing, and Application, Auras, R.; Lim, L.-T.; Selke, S. E. M.; Tsuji, H. (Eds.), Wiley, Hoboken 2010.

2. For example BASF sells since 2007 PLLAs under the trade names Ecoflex ${ }^{\circledR}$ and Ecovio ${ }^{\circledR}$ : http://www.plasticsportal.net/wa/plasticsEU de DE/portal/show/content/literature/ecovio.

3. Kerton, F. M. Alternative Solvents for Green Chemistry, RSC Green Chemistry Book Series, 2009, Cambridge p 103.

4. Wooldridge, M. $\quad$ http://www.lbl.gov/Science-Articles/Archive/carboxylic-acidrecovery.html.

5. Kalck, P.; Urrutigoïty, M.; Dechy-Cabaret, O. Top. Organomet. Chem. 2006, 18, 97.

6. (a) Rucklidge, A. J.; Morris, G. E.; Slawin, A. M. Z.; Cole-Hamilton, D. J. Helv. Chim. Acta 2006, 89, 1783. (b) Rucklidge, A. J.; Morris, G. E.; Cole-Hamilton, D. J. Chem. Commun. 2005, 1176.

7. Kudo, K.; Oida, Y.; Mitsuhashi, K.; Mori, S.; Komatsu, K.; Sugita, N. Bull. Chem. Soc. Jpn. 1996, 69, 1337.

8. Chaudhari, R. V.; Tonde, S. S. US 20050143600, 2005; Chem. Abstr. 2005, 143, 77860.

9. (a) Kiss, G. Chem. Rev. 2001, 101, 3435. (b) Godard, C.; Muñoz, B. K.; Ruiz, A.; Claver, C. Dalton Trans. 2008, 853.

10. Eastham, G. R.; Heaton, B. T.; Iggo, J. A.; Tooze, R. P.; Whyman, R.; Zacchini, S. Chem. Commun. 2000, 609.

11. (a) Cavinato, G.; Toniolo, L. J. Organomet. Chem. 1990, 398, 187. (b) Milstein, D. Acc. Chem. Res. 1988, 21, 428. (c) Kanawa, M.; Nakamura, S.; Watanabe, E.; Urata, H. J. Organomet. Chem. 1997, 542, 185. (d) de la Fuente, V.; Waugh, M.; Eastham, G. R.; Iggo, J. A.; Castillón, S.; Claver, C. Chem. Eur. J. 2010, 16, 6919. 
12. Drent, E.; Hasselaar, M. (Shell), WO 97/03943, 1997; Chem. Abstr. 1997, 126, 185813. (b) Vieira, T. O.; Green, M. J.; Alper, H. Org. Lett. 2006, 8, 6143.

13. Shuklov, I. A.; Dubrovina, N. V.; Börner, A. Synthesis, 2007, 2925.

14. (a) Knifton, J. F. (Texaco) US 4172087, 1979; Chem. Abstr. 1980, 92, 180679. (b) Hayashi, T.; Tanaka, M.; Ogata, I. J. Mol. Catal. 1984, 26, 17. (c) D'Amore, M. B. (Du Pont De Nemours and Co.) US 5026901, 1991; Chem. Abstr. 1991, 115, 207529.

15. Williams, D. B. G.; Shaw, M. L.; Green, M. J.; Holzapfel, C. W. Angew. Chem. Int. Ed. 2008, 47,560 . 